\title{
GERAKAN MEMBUDAYAKAN KEGIATAN MEMBACA PADA SISWA KELAS AWAL SEKOLAH DASAR
}

\author{
Fahrur Rozi, Apiek Gandamana*) \\ Surel: rozipgsd2015@gmail.com
}

\begin{abstract}
The purpose of this study was to carry out a movement to cultivate reading activities for students in the early grades of elementary school (SD). Early class learning emphasizes reading and writing learning skills, followed by learning basic skills and how to use them when learning to read and write and learn strategies to become smooth readers and writers. Then in class 3 and above, students use these skills to learn Subject Information, which is reading to study. So it is necessary to do a movement to cultivate reading in early elementary school students summarized through, 1) Making clear rules governing reading culture activities, 2) Socializing the importance of reading to all parties involved in student education, 3) Applying habit of reading in various interesting activities and 4) Cultivating reading activities consistently and continuously.
\end{abstract}

Keywords: Movement, Reading Culture, Elementary School Students

\section{PENDAHULUAN}

Sekolah Dasar (SD) merupakan tingkatan pendidikan dasar di Indonesia yang berperan dalam pendidikan dan pengembangan dasar-dasar ketrampilan membaca, menulis dan berhitung, khususnya pada siswa kelas awal sekolah dasar. Kemampuan membaca dan menulis merupakan pondasi kesuksesan akademis mereka di masa yang akan datang. Keterampilan-keterampilan menyimak dan berbicara mendukung belajar membaca dan menulis.
Belajar membaca dan menulis adalah suatu proses yang kompleks. Akan tetapi masih ditemukan siswa-siswi di kelas awal SD yang mengalami kesulitan dalam memahami berbagai mata pelajaran yang diperolehnya di sekolah, yang disebabkan oleh banyak hal sehingga hal ini akan berhubungan secara langsung maupun tidak langsung terhadap hasil akademik siswa. Salah satu faktor penghambat siswa dalam memahami pelajaran adalah kesulitan dalam mengikuti pembelajaran adalah rendahnya kemampuan membaca siswa.

*) Fakhrur Rozi, S.Pd., M.Pd., Dosen PGSD FIP UNIMED

Apiek Gandamana,. S.Pd., M.Pd., Dosen PGSD FIP UNIMED 
Pembelajaran di kelas awal lebih menekankan pada ketrampilan belajar membaca dan menulis, dilanjutkan dengan mempelajari keterampilanketerampilan dasar dan cara menggunakannya ketika belajar membaca dan menulis serta empelajari strategi-strategi untuk menjadi pembaca dan penulis yang lancar. Kemudian di kelas 3 ke atas, para siswa menggunakan keterampilanketerampilan tersebut untuk mempelajari Informasi Mata Pelajaran, yaitu membaca untuk belajar.

Akan tetapi pada kenyataannya masih dijumpai siswa-siswa lulusan SD yang belum mampu membaca dengan baik dengan berdasarkan studi lima tahunan yang dilakukan oleh Progress in International Reading Literacy Study (PIRLS) tahun 2006 yang melibatkan siswa SD, Indonesia berada pada urutan 36 dari 40 negara. Hal ini berarti tingkat membaca siswa SD Indonesia hampir berada di urutan terendah. Hasil survey yang dilakukan pada tahun 2013-2014 pada 4800 siswa kelas 2 SD di 400 SD dan MI diperoleh kemampuan membaca sekaligus memahami apa yang dibaca siswa di Indonesia masih sangat rendah (Ester R,M, 2014). Bahkan menurut studi terbaru mengenai minat baca, keadaan keinginan membaca bangsa Indonesia memang cukup memprihatinkan. Berdasarkan studi "Most Littered
Nation In The World" yang dilakukan Central Connecticut State University pada Maret 2016 lalu, Indonesia dinyatakan menduduki urutan ke-60 dari 61 negara mengenai minat membaca. (Gewati, 2016)

Membudayakan siswa untuk membaca bukan hal yang mudah dilakukan akan tetapi tidak juga terlalu sulit untuk dilakssiswaan di Sekolah Dasar (SD). Membutuhkan perhatian dari seluruh stakeholder yang terlibat, sehingga menumbuhkan kegiatan membaca yang berlanjut menjadi kebiasaan sehingga pada akhirnya akan membentuk budaya membaca. Berdasarkan hal tersebut di atas rendahnya kemampuan membaca siswa SD disebakan oleh beberapa hal, diantara; Pertama, Rendahnya pemahaman guru untuk mengetahui tingkat kemampuan membaca siswa sehingga perlakuan yang dilakukan guru terhadap siswa yang lancar membaca sama dengan siswa yang masih belum lancar dan tidak bisa membaca sama sekali, Kedua kegiatan pembelajaran yang dilakukan di sekolah tidak mengarahkan siswa untuk lebih sering membaca, kegiatan membaca hanya dilakukan siswa ketika ditugaskan oleh guru, atau ketika akan mengahadapi ulangan dan ujian, bukan merupakan menjadi kebutuhan mereka. Ketiga, ketika membaca siswa belum memahami maksud yang terkandung di 
dalam buku bacaan mereka, sehingga proses mencari makna dari apa yang dibaca belum dilakukan sepenuhnya oleh guru di kelas. Keempat, kecanduan game, juga mempengaruhi minat baca siswa, mereka lebih sedang menghabiskan berjam-jam waktunya hanya untuk duduk memandangi monitor computer atau handphone dan gadget mereka untuk bermain game atau sekedar memeriksa berbagai media sosial yang mereka miliki. Kelima, minimnya ketersediaan sarana untuk menumbuhkan minat membaca, seperti buku, majalah, pojok baca, perpustakaan. Keenam, dukungan keluarga untuk membudayakan membaca juga masih sangat rendah sehingga baik di rumah maupun di sekolah belum menumbuhkan budaya baca bagi siswa.

Membaca adalah dasar dari pembelajaran di sekolah. Kemampuan membaca berpengaruh besar terhadap mata pelajaran seperti Matematika, Sains, Ilmu Sosial, Bahasa Indonesia dan mata pelajaran lainnya. Siswa yang tingkat kemampuan membacanya rendah akan mengalami kesulitan dalam belajar mata pelajaran lainnya. Adapun tujuan dalam tulisan ini adalah upaya gerakan yang dapat untuk membudayakan membaca di kelas awal di sekolah dasar. Kebiasaan membaca akan membuat siswa belajar kemampuan membaca sejak awal, bukan saja belajar kemampuan dasar membaca, namun membuat mereka mencintai membaca. Dengan mencintai membaca maka keterampilan dan kemampuan membacanya akan terus berkembang dan membaca akan menjadi sebuah kebiasaan baik bagi siswa yang secara perlahan akan berubah menjadi karakter sehingga menjadikan membaca sebagai budaya di sekolah dasar (SD) di Indonesia.

\section{KAJIAN TEORITIS}

Gerakan berarti perbuatan gerakan atau tindakan terencana yang dilakukan sekelompok orang atau masyarakat disertai program terencana dan ditujukan pada suatu perubahan. Kata Budaya diambil dari bahasa Sansekerta yaitu buddhayah yang mempunyai arti bahwa segala sesuatu yang ada hubungnnya dengan akal dan budi manusia. Dalam Kamus Besar Bahasa Indonesia budaya diartikan sebagai pikiran, akal budi atau adat istiadat. Secara tata bahasa, pengertian kebudayaan diturunkan dari kata budaya yang cenderung menunjuk pada pola pikir manusia (Suharso dan Ana Retnoningsih, 2005). Kebudayaan dapat diartikan sebagai semua hal yang berhubung dengan akal pikiran, budi, dan perbuatan manusia yang diperoleh dari kebiasaan-kebiasaan yang telah lama dilakukan. Sedangkan membaca salah satu kemampuan literasi yang harus dimiliki siswa untuk bekal dasar 
dalam mengikuti dan memahami semua pelajaran yang diperolehnya di sekolah.

Membaca adalah perintah dan wahyu pertama yang diturunkan oleh Allah SWT kepada Nabi Muhammad SAW di dalam ajaran agama Islam, artinya membaca memang merupakan sesuatu yang wajib untuk dilakukan bagi siapa saja. Membaca juga akan menjauhkan kita dari kebingungan, karenadapat ditemui dalam kehidupan nyata, bagaimana manusia bisa tersesat, tertinggal atau menjadi bingung dan bodoh karena tidak mau membaca. Begitu banyak tanda-tanda yang ada disekitar kita baik tersurat maupun tersirat yang dapat kita baca sehingga dapat membantu mengatasi masalah dalam kehidupan sehari-hari. Maka sudah seharusnya membaca menjadi budaya yang dapat diterapkan mulai dari pendidikan usia dini termasuk di sekolah dasar. Kemampuan membaca merupakan jembatan menuju pemahaman siswa terhadap semua pelajaran. Dan kemampuan ini harus diajarkan dan dibiasakan.

$$
\text { Membaca permulaan }
$$
merupakan tahap proses belajar membaca bagi siswa sekolah dasar kelas awal. Siswa belajar untuk memperoleh kemampuan dan menguasai teknik-teknik membaca dan menangkap isi bacaan dengan baik. Oleh karena itu, guru perlu merancang pembelajaran membaca dengan baik, sehingga siswa menjadi suka dan terbiasa membaca karena membaca merupakan suatu kegiatan yang menyenangkan. Dengan demikian, guru sangat berperan dalam menumbuhkan motivasi belajar siswa, terutama motivasi belajar membaca.

Salah satu hal pokok yang menjadi pembentuk utama kemampuan membaca permulaan pada anak adalah kesadaran fonologis. Kesadaran fonologis ialah kemampuan untuk mendengar, mengidentifikasi, dan memanipulasi bunyi-bunyi bahasa. Ini merupakan keterampilan lisan dan merupakan kemampu an siswa untuk mendengar dan sadar akan bunyi-bunyi, menggunakan bunyi-bunyi tersebut untuk mengucapkan kata-kata, dan menggunakan bunyi-bunyi tersebut untuk membuat kata-kata baru.

Siswa kelas awal di sekolah dasar adalah siswa yang berada pada kelas 1-3 SD, yang hampir sebagain besar memiliki kesulitan dalam membaca.

Karakteristik kemampuan membaca pada siswa kelas awal yaitu

1. Mulai membaca tanpa memikirkan topiknya dan apa yang mereka ketahui atau menggunakan informasi yang salah.

2. Tidak menentukan tujuan membaca. 
3. Tidak memiliki minat dan motivasi. Membaca tanpa berhenti atau memikirkan apa sedang yang dibaca.

4. Menebak kata berdasarkan konteks, dan mengulang kata yang pernah dibaca.

\section{PEMBAHASAN}

Pada siswa kelas awal sekolah dasar untuk mendukung pelaksanaan budaya baca di sekolah dasar, diantaranya:

1) Membuat aturan yang mengatur kegiatan membadayakan membaca Salah satu langkah nyata yang dilakukan oleh pemerintah dengan mengeluarkan peraturan melalui Peraturan Menteri Kebudayaan (Permendikbud) Nomor 23 Tahun 2015 Tentang Penumbuhan Budi Pekerti. Permendikbud ini berisi tentang setiap sekolah wajib membaca 15 menit sebelum waktu pembelajaran dimulai, khususnya bagi siswa SD, SMP atau SMA. Peraturan ini sangat dibutuhkan sebagai upaya untuk membudayakan membaca di sekolah, sehingga sekolah mau tidak mau harus tunduk dan patuh terhadap peraturan ini. Hal ini juga menjadi dasar bagi pihak sekolah untuk menyusun regulasi secara spesifik dan lebih teknis dalam melaksanakan kegiatan atau program membaca bagi siswa. Kegiatan ini akan memiliki dampak yang baik terhadap kegiatan siswa di pagi hari untuk mau membaca minimal 15 menit sebelum memulai pelajaran. Dalam melaksanakan regulasi ini yang diperlukan adalah konsistensi sekolah dalam melaksanakannya, serta juga adanya pengawasan untuk menjamin kegiatan ini terlaksana dan berkesinambungan. Sehingga dengan berkelanjutan diharapkan akan menimbulkan kebiasaan-kebiasaan yang menghasilkan karakter dan menghasilkan budaya membaca

2) Melakukan sosialisasi pentingnya membaca ke seluruh pihak-pihak yang terlibat dalam pendidikan siswa

Membangun gerakan budaya membaca di Sekolah Dasar sangat penting untuk memberikan edukasi terhadap pihak-pihak terlibat (stakeholder) seperti kepala sekolah, guru, siswa, orang tua dan masyarakat sekitar sekolah tentang pentingnya membaca. Guru adalah salah satu kunci utama untuk mendukung gerakan ini. Maka sangat diperlukan untuk mengedukasi guru dan kepala sekolah tentang pentingnya membaca dalam bentuk pelatihan 
atau workshop sehingga ada kesamaan dalam mengembangkan ketrampilan guru dalam hal membaca. Ketrampilan yang telah diperoleh guru tentunya akan berguna untuk mengajarkan siswanya agar dapat membaca dengan baik dan benar juga akan sangat membantu suksesnya gerakan ini. Berikut ini adalah beberapa strategi membaca yang seharusnya dimiliki guru agar dapat mengajarkan ketrampilan membaca kepada siswanya.

a) Membaca Bersama dengan menggunakan Big Book Kegiatan ini menggunakan buku dengan teks yang diperbesar agar terbaca oleh semua siswa. Kegiatan Membaca Bersama melibatkan semua siswa dalam satu kelas. Guru memodelkan berbagai keterampilan membaca dan melibatkan siswa selama proses membaca dilakukan. Keterampilan yang dilatihkan dalam kegiatan Membaca Bersama adalah memprediksi, memahami kosakata dan tanda baca, memahami isi bacaan, dan merangkum/meringkas. b) Membaca Terbimbing dengan menggunakan buku bacaan berjenjang Kegiatan ini dilakukan di kelompok kecil beranggotakan siswa dengan kemampuan membaca yang sama (homogen). Guru memilih dan memperkenalkan buku baru serta membimbing setiap siswa dalam membaca dan memahami seluruh bacaan. Bimbingan diberikan sebelum, saat, dan setelah membaca.

c) Membaca Mandiri dengan menggunakan buku yang disukai siswa.

Siswa membaca berbagai buku secara individu atau berpasangan. Buku yang dibaca bisa diambil dari koleksi buku yang dimiliki sekolah. Bahan bacaan juga bisa diambil dari paket buku berjenjang sesuai tingkat kemampuan membaca siswa, atau juga buku yang dibawa siswa dari rumah.

$$
\begin{aligned}
& \text { Selain tiga strategi } \\
& \text { mengajarkan membaca di } \\
& \text { atas, guru juga melakukan } \\
& \text { penilaian terhadap } \\
& \text { kemampuan membaca } \\
& \text { siswa sehingga dapat }
\end{aligned}
$$




\begin{tabular}{|c|c|}
\hline diketahui & pentingnya \\
\hline kemampuan & membaca di keluarga dan \\
\hline seperti & ketika berada dilingkungan \\
\hline membaca (tinggi) & sekolah, melalui pertemuan \\
\hline Berkembang (sedang), dan & dengan pihak sekolah atau \\
\hline mulai (rendah). Dengan & juga melalui tulisan yang \\
\hline demikian guru dapat & menghimbau \\
\hline melakukan tindakan yang & agar berperan aktif dalam \\
\hline tepat dalam mengatasi & mensukseskan \\
\hline
\end{tabular}
siswanya. Masih banyak ditemui siswa di kelas tinggi (kelas 4-6) SD yang belum lancar membaca, tetapi diharuskan membaca buku teks pelajaran yang panjang dan susah kosakatanya, oleh karena itu harus diajarkan strategi membaca di atas sejak kelas awal (kelas satu) SD. Ketika siswa disuruh untuk membaca satu halaman dan siswa mengalami kesulitan membaca lebih dari lima kesalahan maka siswa dapat dikategorikan mengalami kesulitan membaca, sehingga siswa tersebut perlu bimbingan dalam membaca ini disebut strategi lima jari (USAID Prioritas, 2016: 20).

Orang tua dan masyarakat sekitar sekolah juga perlu memperoleh edukasi mengenai

3) Menerapkan kebiasaan membaca secara dengan berbagai kegiatan yang menarik Setelah memberikan edukasi yang tepat maka harus diaplikasikan dalam bentuk yang konkrit untuk menumbuhkan budaya membaca bagi siswa SD. Berikut ini adalah beberapa kegiatan yang dapat dilakukan pada tahapan ini:

a) Membuat kegiatan membaca berimbang di sekolah (membaca bersama, membaca terbimbing dan membaca mandiri di sekolah) 15 menit sebelum pelajaran di mulai. Seperti kegiatan SERASA MEMBARA (Selasa, Rabu, Sabtu, Membaca Gembira). Agar waktu pembelajaran tidak terganggu sekolah dapat melakukan penyesuaian jadwal seperti masuk lebih awal 15 menit 
pada hari-hari yang telah ditentukan. Kegaiatan jiga ini dilaksanakan setiap hari di banyak negara seperti Amerika Serikat, Australia, Inggris, Singapura, Malaysia, dan Brunei dengan bermacam nama seperti SURF (Sustained Uninterrupted Reading for Fun/Membaca Tanpa Interupsi untuk Kesenangan), DEAR (Drop Everything and Read/Letakkan Segala Sesuatu dan Baca), Book Flood (banjir buku), dsb. Sebuah madrasah ibtidaiyah di Blitar memberi nama Iqro' Time, dan sebuah SD di Malang memberi nama Membaca, Yes! pada kegiatan ini. (USAID Prioritas, 2014:377).

b) Melakukan kegiatan WACANA (Wajib Baca Semuanya) yang dilakukan di luar kegiatan membaca berimbang, contohnya di hari Jumat, disediakan waktu selama setengah jam agar seluruh warga sekolah seperti (kepala sekolah, guru, tata usaha, petugas keamanan, guru, siswa dan bahkan orang tua yang mengantarkan anaknya ke sekolah diajak terlibat) dapat membaca buku, di tempat terbuka, seperti di halaman sekolah, di depan kelas, di bawah pohon rindang, agar memberikan nuansa positif semangat dan keteladanan bagi siswa agar mau membaca. Karena satu keteladanan lebih baik daripada seribu nasehat atau perintah.

c) Mengelola MADING (Majalah Dinding) dan MAKE UP (Majalah Kelas Untuk Pelajaran), sekolah menyediakan tempat untuk menampilkan tulisan di beberapa sudut sekolah dan juga di dalam kelas yang berisi mengenai tulisan yang menarik bagi siswa, yang dikelola oleh siswa dan dibimbing oleh guru. Juga dapat membuat POKBA (Pojok Baca) di pojok sekolah yang tidak terpakai untuk disediakan tempat dan buku bacaan yang menarik.

d) Melakukan kegiatan $B A C A$ SAJA (Membaca Satu Jam) yang melibatkan orangtua dalam pendampingan dan pengawasan membaca di 
rumah, dihimbau agar di rumah siswa untuk belajar termasuk membaca buku pelajaran. Mematikan TV dan melarang penggunaan gadget minimal 1 jam di malam hari. Sehingga siswa dapat fokus terhadap pelajarannya dan terbiasa membaca.

e) Memberdayakan sarana perpustakaan sebagai salah satu sumber bacaan, oleh karena itu guru dapat mengajak siswa melakukan pembelajaran di perpustakaan dengan mengajak siswa mencari sumber informasi baru melalui membaca bukubuku yang ada di perpustakaan

f) Sekolah mengadakan pameran dan bazar buku yang dapat dilakukan di akhir semester untuk memancing minat siswa untuk membeli buku dan membaca buku.

g) Mengadakan perlombaan membaca seperti membaca puisi, membaca dongeng, membaca ayat-ayat suci untuk mengapresiasi kemampuan siswa dalam membaca. Siswa akan berusaha menjadi yang terbaik, hal ini akan memnambah motivasi siswa untuk terus mau membaca (Kasiyum, S., 2015)

4) Membudayakan kegiatan membaca secara konsisten dan berkelanjutan

Dalam melaksanakan sebuah gerakan diperlukan determinasi dalam arti gerakan ini harus didasari ketetapan hati dalam mencapai maksud dan tujuan yaitu menumbuhkan budaya baca. Dengan determinasi yang tinggi dari semua pihak yang akan menjadikan gerakan ini berkelanjutan yang akan membentuk kebiasaan dan kebiasaan akan menghasilkan karakter dan akhirnya akan tercipta budaya baca bagi siswa di Sekolah Dasar (SD). Kegiatan yang telah dilaksanakan, tentu juga harus memiliki tujuan dan target, maka konsistensi dan monitoring juga sangat diperlukan untuk keberhasilan gerakan ini.

\section{SIMPULAN}

Salah satu faktor penghambat siswa dalam memahami pelajaran adalah kesulitan dalam mengikuti pembelajaran adalah rendahnya 
kemampuan membaca siswa. Dari beberapa studi dan survey menunjukkan tingkat membaca siswa SD Indonesia hampir berada di urutan terendah dari negara lain. Kemampuan membaca merupakan jembatan menuju pemahaman siswa terhadap semua pelajaran. Maka sudah seharusnya membaca menjadi budaya yang dapat diterapkan mulai dari pendidikan usia dini termasuk di sekolah dasar. Banyak hal yang dapat dilakukan untuk menumbuhkan budaya baca, salah satu gagasan yang dapat ditawarkan yaitu dengan melakukan, Membuat aturan yang jelas yang mengatur kegiatan membudayakan membaca, Melakukan sosialisasi pentingnya membaca ke seluruh pihak-pihak yang terlibat dalam pendidikan siswa, Menerapkan kebiasaan membaca secara dengan berbagai kegiatan yang menarik dan Membudayakan kegiatan membaca secara konsisten dan berkelanjutan serta bertanggungjawab untuk mendukung pelaksanaan budaya baca di sekolah dasar.

\section{DAFTAR PUSTAKA}

Ambruster, B., F. Lehr, Osborn, J. 2001. Put Reading First, Kindergarten to Grade 3: The Research Building Blocks for Teaching Children to Read. National Institute for Literacy.
Austin, Michael. 2007, Reading the World: Ideas That Matter. W.W. Norton,

Gunning, T.G. 2001. Creating Literacy Instruction for All Children (3rd ed.). Boston: Allyn \& Bacon.

Gewati M,. 2016. Minat Baca Indonesia Ada di Urutan ke-60 Dunia. Jakarta. Kompas.com (29 Agustus 2016) diunduh 10 Oktober 2017.

Kasiyum, S. 2015. Upaya Meningkatkan Minat Baca Sebagai Sarana Untuk Mencerdaskan Bangsa.Surabaya: Jurnal Pena Indonesia (JPI) Jurnal Bahasa Indonesia, Sastra dan Pengajarannya, Vol. 1, No.1Maret 2015:80-95.

Suharso dan Ana Retnoningsih. 2005. Kamus Besar Bahasa Indonesia. Semarang: Widya Karya.

USAID Prioritas. 2014. MODUL II Praktik yang Baik di SD dan MI. Jakarta: USAID Prioritas.

USAID Prioritas. 2016. Modul Pelatihan III A Praktik yang Baik di SD dan MI, Pembelajaran Membaca di Kelas Awal. Jakarta: USAID Prioritas. 